\title{
Minority Community Students' Experience of Foreign Language Learning: A Narrative Inquiry
}

\author{
Surya Sigdel \\ Tribhuvan University Mahendra Ratna Campus Kathmandu
}

\begin{abstract}
This study explores minority community students' feelings and experience of English language learning in multilingual classroom and how they respond towards dominant languages and their mothertongue. The information to be discussed was received from classroom observation and narratives of eight Tamang students of two secondary schools of Nuwakot, Nepal. It was found that they experience dominance linguistically, culturally and socioeconomically. The linguistic environment in context of classroom and society, nation's language policy and global linguistic environment have sustained supremacy. This dominance is reflected through different sorts of behaviors and verbal and nonverbal means of communication that take place in the classroom as it does in the society they live. The participants' stories expose the need of dominant languages and how the languages along with their culture affect their participation in English language classroom activities. Besides, it depicts how linguistic, cultural and socio-economic environment, language policy and global influences discourage the students from minority communities to participate actively in the traditional classrooms. In order to mitigate the students' uncomfortable feeling, teachers' role to handle multilingual students, appropriate language learning environment and child friendly classroom activities are a must.

Key words: Tamang student, multilingual, minority community, dominance, dominant language.
\end{abstract}

\section{Introduction}

The students who are from the same socio-cultural and linguistic background in the class can better understand when teachers use English or their mother-tongue. But in a multilingual classroom, students have different mother tongues, artifacts and norms and values. In this situation, the group whose mother tongue is used as a medium of instruction can better learn than those who have difficulty even in understanding the language (the language of medium of instruction). As Nalunga[4] states Nelson Mandela's remark, "If you talk to a man in a language he understands, that goes to his head. If you talk to him in his language, that goes to his heart (p. 4)". Students from minority community whose mother-tongue is different from the medium of instruction have difficulty even in understanding the language (the medium of instruction) and it has impeded them to understand what they are taught in English language classroom. Furthermore, the students, being L1 speakers of the language (language as a medium of instruction), can have better rapport with the teacher whose mother tongue is the same.

In multilingual classroom, the students whose mother-tongue is the medium of instruction have more benefits than those who have difficulty in understanding the language, medium of instruction. As it is said, "Birds of a feather flock together", we have birds with different feathers to be flocked together. For example, the students from the same cultural, ethnic and linguistic background enjoy learning together and stretch ahead but the students from diverse cultural, ethnical and linguistic background feel inferior. As Central Bureau of Statistics [2] has stated that Nepal is a multicultural, multiethnic and multilingual country with 123 languages, our community is mixed up with the people from these diverse cultures. Each language has its own identity with distinct cultures. Each culture has their own norms and values so are their perceptions and understandings as well. Our community is mixed up with the people from these diverse cultures. School is the center where children gather and stretch with their learning. This shows that majority of the schools consists of students with different mother-tongues.

The purpose of the study was to investigate minority community students' feeling and experience of English language learning in multilingual classrooms and how they respond towards dominant languages and their mother-tongues. If the students can lead the learning of their mother-tongue and target language equally, they could enjoy global opportunity and maintain their ethnic identity.

\section{Research Method}

As life experiences, narrative stories and field notes are the bases of knowledge, I explored the realities of Tamang students' English language learning experiences from their life stories, lived experiences and observation. I used interpretive paradigm as methodological guideline and narrative inquiry as a research method. Using purposive and snowball sampling, I chose eight Tamang students as they are the largest minority group in Nepal (Census, 2011) and they are one of the least advanced minority groups. The respondents were regular, 
passed out and dropped out students of secondary level (from grade nine to twelve). They would speak the Tamang language or language variety with their parents and close relatives, use Nepali language to communicate with those who would not speak their first language and were learning English in schools. I also visited elderly people, women and educated Tamang people and talked with them about their perception and understanding about their language and culture and dominant languages and cultures.

\section{Linguistic Experience}

Tamang students have difficulty in pronouncing ' $a$ ' and 'aa'. For example, when they pronounce computer, they pronounce as /kam'pju..tar/ whereas the correct pronunciation is /kəm'pju:tər/. It has created a sort of hesitation and nervousness in them while speaking words from another language.

When a Tamang language speaker pronounces a consonant sound, he or she pronounces it adding /a/ which deviates pronunciation and meaning sometimes. For example, sanchai chha? / सज्चै छ? (Are you fine?) becomes saanchai chhaa? / सान्चे छा (Are you fine?). It has deviation only in pronunciation not in meaning. In some situations, it becomes weird and creates a great misunderstanding. For example: Gai maryo ra haamle khayo/गाई मर्यो र हाम्ले खायो (Cow died and we ate) becomes Gai maaryo ra hamle khaayo/ गाई मार्यो र हाम्ले खायो (we killed cow and ate). In this way, meaning digresses and creates a sort of misunderstanding. Being a beefeater in Hindu community where cow, a national animal of Nepal, is worshipped as Maata (mother), Tamang people are hated, dominated and isolated. Even in the use of language, a Tamang speaker becomes a cow killer which is not only against social norms and value but also against the law.

Since Nepali was not their first language, they speak Nepali with different accent. It was one of the causes that their peers and teachers insult and humiliate them in the classroom. In Tamang language, they do not have honorific distinction in the second person pronoun i.e., ellaa 'you'. This leads them to address their teachers and seniors with timi (you) and for a Nepali speaker the word timi for a teacher is nonhonorific in the hierarchy. This difference has led their peers and teachers to treat them as if they were rustic and impolite belonging to working class who use low variety of language.

\section{Socio-cultural and Economical Impacts}

Tamang people's socio-economic, cultural and familial situation and social practices are other factors to create inferiority. Tamang culture is different from other cultures within the community. They were blamed as unsacred people. A newly born
Tamang baby is/ used to be baptized on the sixth day of her/his birth by his/her own parents, not by the priest or Lama. Tamang women, like other women in Hindu culture, are not untouchable during their menstrual period. They have no refraining custom (chhaupadi pratha) during menstrual period. Tamang ladies do not change their clan and lineage (Thar and gotra) after their marriage. Even after the death of a married Tamang lady, nearest people from her parental lineage touch and perform funeral ceremony. They eat beef which is a taboo in Hindu custom. Moreover, they have to learn English stories from Hindu cultures and social contexts. It leads them to feel that their language and culture is not genuine and good enough to be published in the book for study.

Children's education has been influenced by their parents' socio-economic status, awareness level, and educational status. The children, whose parents were poor, illiterate, and traditional, were dejected and isolated in the study. It is clear from educated, aware and prosperous Tamang people's voice that their minority language is just for speaking in that locality. For better career, Nepali and English are required.

Children who have pathetic situation in the family require a hope of consolation, support and protection but they are found to have been dominated, ignored and isolated even in their classrooms. Children who cannot give time to study at home, cannot complete their assignment and prepare for the next day class are more likely to be affected. For example, Tamang girl students who make wine, ale and food; do all sorts of household works; take wine to sell to the hotels while going to school and have no time even to touch their books are found to have been ignored, insulted and discouraged in their study.

Tamang people are also found to have been isolated and dominated not only by upper class people but also by their own prosperous group. As Rai [1] states "timi afnai gharma afain baas namaga" (You do not ask for a shelter in your own house). Some of college students from the minority group claim that the fall of their ethnic identity is also the fault of prosperous group within the ethnicity. They said, "They played no roles to uphold our caste's status, instead, they used our name and ethnicity for their personal benefit not for the benefit of the group as a whole." They also claimed that educated Tamangs move to the urban areas and enjoy a number of opportunities in the name of minority group and hardly support to those who have no money even to buy pencil and copy. They engulfed a heavy amount in the name of preserving and promoting the Tamang language and culture but did nothing. The custom of drinking, the trend of early marriage, poverty and lack of awareness have discouraged the Tamang children to participate actively in the classroom. 


\section{Nation's Language Policy}

Government's language policy and people's practice and attitude seem completely contrasting. After Jana Andolan I /People's Movement I (1990), the government has provisioned the right of mother tongue as a medium of instruction in Basic/Primary level Education. Reservations on the basis of races/ indigenous groups, gender, disability, Madhesi, disadvantaged and marginalized, but not on the basis of language and culture have driven people away from their language and culture. There is $45 \%$ reservation, that is to say, only in $55 \%$ positions; everyone can compete openly without any reservation from any groups. As Civil Service Act 2049, amended in 2073 [3], clause 7.7 states that out of the $45 \%$ of the reservation, every advertisement has secured certain positions for different ethnic groups and remote areas. out of this $45 \%$ positions, $33 \%$ is for female, $27 \%$ is for Indigenous/ Janajati, 9\% for Dalit, 22\% for Madhesi, $5 \%$ for Disabled and $4 \%$ for remote area are distributed. The policy has no reservation for the promotion of language and culture. When there is right of education in mothertongue, there should be a provision to encourage people to promote their mother-tongue and even to pursue career from their mother-tongues. Only then, the community would be encouraged to promote their language and culture.

\section{Practice and Attitude}

The more rural area the people live, the better and more typical mother-tongue they have. The more urbanized area they live, the better dominant language they have and the better access they have. Therefore, Tamang parents were found to encourage their children to learn English and Nepali not their own language in later days. Those who had learned their L1 were regretting. Localization has been slowly and gradually turned into and moved ahead towards globalization. People are using English terms replacing their mother-tongue vocabulary and Nepali terms one after another. They were found to feel being superior while inserting English terms when they converse either in Nepali or in their mother-tongue.

\section{Power Structure in the Classroom}

Power always plays the crucial role to form any kind of structure. The structure ultimately tries to convey certain information which can be interpreted as a form of knowledge, and that knowledge ultimately linked with power which always tries to influence truth. Language is a tool to create power. The students who can speak confidently in the classroom seem more powerful than those who speak non-standard variety and dominated languages. van Dijk [5] believes that the elites dominate others with the power of wealth, income, position, status, force, group membership, education or knowledge which are socially valued resources. Students with socially valued recourses have higher status, better confidence and less likely to feel nervous.

\section{Global Influence}

Globalization is a social process which promotes cross cultural contact. For cross cultural communication, people need a lingua franca that is English without which global access has been impossible. We need English in schools and colleges, in travel, in work places and even in hospitals and shopping malls. Because of this tendency, code switching and code-mixing takes place now and often. The trend of mixing a word/ words from dominant language while speaking dominated language is more usual and acceptable than the word/words from dominated languages while speaking a dominant language. For example, while speaking Nepali, mixing of English words are usual and well acceptable but mixing of Nepali words while speaking English seems less usual and less acceptable. So is the case of Nepali and Tamang language where Nepali is dominant and Tamang is dominated.

Malaai tesko baarema kehi idea nai chhaina saar $=\mathrm{I}$ have no idea about that sir.

Yella (your) buddhi (idea) aare (no) =You have no idea.

Ea (your) Ghey (work) lava (do) tarika (idea) aare $($ no $)=$ You have no idea to work.

Mixing word/words from dominant language/languages while speaking a dominated language is a matter of superiority. When we mix a word/ words from a dominated language while speaking a dominant language, it seems to be odd and deformed. And sometimes it is a shock and sometimes, it creates laughter.

\section{Conclusion}

Learners from minority communities like Tamang students experience dominance in English language classrooms. Sometimes dominance is implicit and sometimes it is explicit. No child feels superior or inferior by birth. They feel and experience it later as they get involved in different activities and come in touch with different people in the society. However, it begins from their family and pervades with their contact with others. The dominance that Tamang students feel and experience in English language classroom is closely related to the local and global influences. Familial, sociocultural, economical and classroom environment are 
the bases where language dominance appears and flourishes.

Due to the difference in pronunciation, Tamang students are teased and insulted. Every language is different from others in phonology, morphology, syntax and semantics. This difference is their identity, but it has become a tool for isolation and an object to tease and dominate them. Thus, the linguistic dominance creates the sense of inferiority complexion and it prevents them from active participation in the classroom activities.

Psychologically, the inferior complexity bares them from active participation in English language classroom activities. Our education policies, practices of teachers and social attitudes towards minority communities are responsible for this inferiority complexion on minority communities like Tamang. They are hegemonized with the notion that the children of Brahmins/ Chettris (upper class people) are born with sharp minds and children of Tamangs are born blunt and they are not meant for higher level of learning. This hegemonic conception of social stratum reduces the confidence level of Tamang learners while participating in classroom activities.

Classroom structure, teacher and medium of instruction seemed to be power designer. In classroom structure, the teacher possesses power and students are influenced with that power. The students whose values, beliefs and convictions are similar to that of teacher have better relationship and higher status than those whose values, beliefs and convictions are different. Language is a tool to create power and so is knowledge. The students whose mother-tongue is the same as the medium of instruction feel superior and speak more confidently than those whose mother-tongue is different from the medium of instruction. They have less confidence even in the use of the language, the medium of instruction.

Cultural practices, classroom environment and people's attitude are the next influential factors for the creation and promotion of dominance in classroom activities. Tamang people are found to be superstitious because they have high respect to Lama and they cannot go against his order. This respect to their superstition confined them within their circle. Due to the difference in culture, they are blamed to be irreligious, non-sacred and sometimes even criminal and were/are treated in the same way. Most of the Tamang people in the rural areas are uneducated or less educated. It has affected their children's study. The students whose parents are educated and/or aware of education get support and supportive environment and studious culture in the house. But those whose parents are uneducated or less educated and unaware of the value of education cannot concentrate in study. They also have no study environment in the house. They go to the class with no assignment and defeated mentality. This results their weak participation in classroom activities. Classroom environment is not motivating for study.

This has increased the dropped-out. The trend of getting married in early age and going abroad for employment and the culture of eating, drinking and relaxing leads them to be lagged behind in study.

Teachers have a great role to lead their students in learning. If teachers are trained to handle multilingual students, to create appropriate language learning environment and to run child friendly classroom activities, students can lead their mothertongue and English significantly.

\section{References}

[1] Bhattachan, K. B. (2009). Indigenous people and minority of Nepal (Unpublished final report). MRG, International, Nepal.

[2] Central Bureau of Statistics. (2011). National population and housing census. Kathmandu: Author.

[3] Civil Service Act (2049, amended in 2073). Nepal Law Commission, Kathmandu.

Education Act (2028/19972) 9th amendment-2017. Nepal Law Commission, Kathmandu.

[4] Nalunga, M. L. (2013). Teaching and learning English in a multilingual classroom: A study of code switching in an EFL/ESL teaching/learning situation. Retrieved from: https://www.diva-

portal.org/smash/get/diva2:704152/FULLTEXT01.pdf

[5] Van Dijk, T.A. (1993). Principles of critical discourse analysis. Discourse and Society, 4(2), 249-283.

\section{Acknowledgements}

I would like to express my humble gratitude to Dr. Rishi Ram Rijal, Head of Department of English Education, Mahendra Ratna Campus for his support and constructive feedback, the participants for sharing their insights and experiences and the head teacher of the school for the permission of the study 